\title{
PENGARUH FASILITAS BELAJAR DAN PERAN GURU TERHADAP HASIL BELAJAR ONLINE SISWA \\ (Survei Pada Mata Pelajaran Ekonomi Semester Ganjil Tahun Ajaran 2021/2022Kelas X BDP SMK Pasundan 4 Bandung) \\ ${ }^{1}$ Ani Setiani, ${ }^{2}$ Yudho Ramafrizal S, ${ }^{3}$ Leni Maryani, ${ }^{4}$ Veri Aryanto \\ Sopiansah, ${ }^{5}$ Deden Regito \\ Universitas Pasundan \\ ${ }^{12345}$ anisetiani@unpas.ac.id, yudhoramafrizal@unpas.ac.id, lenimaryani@unpas.ac.id, veriaryanto@unpas.ac.id, Regito.deden123@gmail.com
}

\begin{abstract}
This study aims to determine the effect of learning facilities and the role of teachers on online learning outcomes in odd semester economics subjects in class $X$ BDP SMK Pasundan 4 Bandung. The method used in this research is a survey. The subjects in this study used a sample of 56 students. The data analysis used is descriptive analysis, classical assumption test and hypothesis testing through multiple linear regression calculation and coefficient of determination with the help of SPSS 25.0 for Windows. From the results of research on hypothesis testing, multiple linear regression coefficients $(Y=1.638-0.513 X 1+0.577 X 2+0.347)$ which means that if learning facilities (variable $X 1$ ) and the role of teachers (variable $X 2$ ) increase, it will cause a tendency to increase student online learning outcomes. (variable X2). Y) of 1.09. The contribution of the influence given by the learning facilities variable to students' online learning outcomes is $34.5 \%$ and the teacher's role variable to students' online learning outcomes is $35.8 \%$, the percentage is calculated based on the results of the calculation of the coefficient of determination of $70.3 \%$, while the remaining $29.7 \%$ is influenced by external factors not examined by the researcher, and the conclusion is acceptable. As the end of the research, the author conveys suggestions for schools for learning facilities and teachers to use adequate learning facilities in the ongoing teaching and learning process, especially in learning facilities and the role of teachers in general so as to improve student online learning outcomes.
\end{abstract}

Keywords: Learning Facilities, Teacher's Role, Learning Interest.

\begin{abstract}
ABSTRAK
Penelitian ini bertujuan untuk mengetahui pengaruh fasilitas pembelajaran dan peran guru terhadap hasil belajar online pada mata pelajaran ekonomi semester gasal di kelas X BDP SMK Pasundan 4 Bandung. Metode yang digunakan dalam penelitian ini adalah survei. Subyek dalam penelitian ini menggunakan sampel 56 siswa. Analisis data yang digunakan adalah analisis deskriptif, uji asumsi klasik dan pengujian hipotesis melalui perhitungan regresi linier berganda dan koefisien determinasi dengan bantuan SPSS 25.0 for Windows. Dari hasil penelitian pada uji hipotesis, koefisien regresi linier berganda $(Y=1,638-0,513 X 1+0,577 X 2+0,347)$ yang artinya jika fasilitas belajar (variabel X1) dan peran guru (variabel X2) meningkat maka akan menyebabkan kecenderungan meningkat hasil belajar online siswa (variabel $\mathrm{X} 2$ ). Y) dari 1,09. Kontribusi pengaruh yang diberikan variabel fasilitas
\end{abstract}


belajar terhadap hasil belajar online siswa adalah $34,5 \%$ dan variabel peran guru terhadap hasil belajar online siswa adalah 35,8\%, persentasenya dihitung berdasarkan hasil perhitungan koefisien determinasi sebesar $70,3 \%$, sedangkan sisanya sebesar $29,7 \%$ dipengaruhi oleh faktor eksternal yang tidak diteliti oleh peneliti, dan kesimpulannya dapat diterima. Sebagai akhir dari penelitian, penulis menyampaikan saran bagi pihak sekolah untuk fasilitas belajar dan guru untuk menggunakan fasilitas belajar yang memadai dalam proses belajar mengajar yang sedang berlangsung, khususnya pada fasilitas pembelajaran dan peran guru pada umumnya sehingga dapat meningkatkan hasil belajar online siswa.

Kata Kunci: Fasilitas Belajar, Peran Guru, Minat Belajar

\section{PENDAHULUAN}

Pengembangan sumber daya manusia adalah melalui pendidikan karena pendidikan diyakini sebagai salah satu bidang yang memiliki peran penting dan strategis dalam pembangunan suatu bangsa. Betapa penting dan strategis peranan pendidikan di dalam pembangunan bangsa, hal tersebut telah diakuai sejak dirumuskannya UUD 1945.

Pendidikan adalah proses yang dialami seseorang untuk dapat mengeksplor potensi dan bakat diri, meningkatkan kecerdasan, keterampilan, mempertinggi budi pekerti, memperkuat kepribadian, meningkatkan kekuatan spiritual keagamaan dan mempertebal semangat kebersamaan agar dapat membangun diri sendiri dan bersama-sama membangun bangsa dan negara. Menurut Undang-undang Republik Indonesia No. 20 tahun 2003 tentang Sistem Pendidikan Nasional Bab I pasal 1 menyatakan:

"Pendidikan merupakan usaha sadar dan terencana untuk mewujudkan suasana belajar dan proses pembelajaran agar peserta didik secara aktif mengembangkan potensi dirinya untuk memiliki kekuatan spiritual keagamaaan, pengendalian diri, kepribadian, kecerdasan, akhlak mulia, serta keterampilan yang diperlukan dirinya, masyarakat, bangsa, dan negara."

Untuk dapat mewujudkan tujuan nasional dalam bidang Pendidikan maka pemerintah dan sekolah harus bisa memberikan fasilitas untuk kegiatan Pendidikan. Fasilitas belajar disini merupakan sarana prasarana untuk menunjang kegiatan pembelajaran. Prasarana meliputi gedung sekolah, ruang belajar, lapangan olahraga, ruang ibadah, ruang kesenian dan peralatan olah raga. Sarana pembelajaran meliputi buku pelajaran, buku bacaan, alat dan fasilitas laboraturium sekolah dan berbagai media pembelajaran yang lain. Maka dari itu pemerintah dan sekolah harus mempunyai berbagai terobosan, salah satunya pemenuhan sarana dan prasarana pendidikan untuk menunjang jalannya proses Pendidikan untuk mencapai tujuan dalam Pendidikan itu sendiri. Fasilitas belajar yang dilakukan di SMK Pasundan 4 Bandung tepatnya dikelas X BDP menunjukan hasil belajar siswa yang menurun. Berikut data siswa kelas X BDP: 
Table 1

Rekap Nilai Siswa Kelas X BDP SMK Pasundan 4 Bandung

\begin{tabular}{|l|l|l|}
\hline Nilai & Jumlah iswa & Predikat \\
\hline $\mathbf{1 0 - 3 0}$ & - & - \\
\hline $\mathbf{3 0}-\mathbf{5 0}$ & - & - \\
\hline $\mathbf{5 0}-\mathbf{7 0}$ & 22 & $\mathrm{C}$ \\
\hline $\mathbf{7 0}-\mathbf{9 0}$ & 34 & $\mathrm{~B}$ \\
\hline $\mathbf{9 0}-\mathbf{1 0 0}$ & - & - \\
\hline
\end{tabular}

Tabel diatas menunjukan jumlah siswa paling banyak terletak pada interval 30-80 sebanyak 28 siswa dan paling sedikit terletak pada interval 40 sebanyak 1 siswa. Hal ini dapat dilihat dari proses pembelajaran yang dilaksanakan di SMK Pasundan 4 Bandung bahwa fasilitas belajar online dan peran guru dirasa masih kurang memadai terhadap hasil belajar siswa pada mata pelajaran Ekonomi di SMK Pasundan 4 Bandung.

Selain dari fasilitas belajar, peran seorang guru dalam dunia Pendidikan sangatlah penting dalam proses belajar mengajar dan dianggap paling dominan Menurut uzer Usman (Amiruddin 2013, hIm 03) menyatakan :

"peran guru secara umum adalah sebagai tugas pendidikan meliputi mendidik, mengajar dan melatih, Peran guru dalam menjalankan tugas disekolah harus dapat menjadikan dirinya sebagai orang tua kedua dan mampu menarik simpati para siswa sehingga pelajaran apapun yang diberikan hendaknya dapat menjadi motivasi bagi siswanya dalam mengajar."

Hal tersebut harus berjalan seiring, tidak ada yang mendahului antara mengajar dan belajar karena masing-masing memiliki peran yang memberikan pengaruh satu dengan yang lainnya. Pada tahun 2020 tepatnya di bulan februari wabah penyakit covid-19 sudah menyebar ke Indonesia, yang mengakibatkan semua sektor yang ada dinegara kita harus dilakukan secara online, salah satunya sektor Pendidikan, dimana kegiatan pembelajaran harus dilakukan secara online. Namun, fasilitas belajar dan peranan guru dinegara kita dalam mengahadapi pembelajaran online belum cukup memadai.

Dilihat dari kesiapan fasilitas yang dimiliki sekolah - sekolah dinegara kita belum sepenuhnya terpenuhi. Pemerintah sudah berupaya memenuhi fasilitas belajar online secara bertahap. Selain itu guru merupakan satu factor yang cukup berpengaruh dalam memberikan fasilitas belajar online terhadap siswa. Guru diharapkan mampu menguasai teknologi untuk menunjang fasilitas belajar online, sehingga kegiatan pembelajaran dapat berjalan secara efektif.

Hasil belajar merupakan bagian paling penting dalam proses pembelajaran. Menurut Jihad dan Haris (2012, hlmn 14) mengatakan bahwa hasil belajar merupakan pencapaian bentuk perubahan perilaku yang cenderung menetap dari ranah kognitif, afektif, dan psikomotoris dari proses belajar yang dilakukan dalam waku tertentu.

Berdasarkan latar belakang latar belakang masalah di atas, maka dapat dirumuskan masalah sebagai berikut: Seberapa besar pengaruh fasilitas belajar dan peran guru terhadap hasil belajar online siswa di SMK Pasundan 4 Bandung? 


\section{LANDASAN TEORI}

1. Pengertian Fasilitas Belajar

Dalam pendidikan memiliki bebrapa komponen pembelajaran yang dapat menunjang kegiatan belajar mengajar. Salah satu komponen tersebut meliputi fasilitas belajar. Bafadal (2014, hlmn 02) menerangkan perlengkapan sekolah atau sering disebut dengan fasilitas sekolah, dapat dikelompokan menjadi sarana Pendidikan dan prasarana Pendidikan.

Menurut Muhroji dkk dalam Pekik Wicaksono (2012, hlmn 10) "Fasilitas belajar adalah semua yang diperlukan dalam proses belajar mengajar baik bergerak maupun tidak bergerak agar tercapai tujuan pendidikan dapat berjalan lancar, teratur, effektif, dan efisien".

Dari beberapa pengertian diatas dapat disimpulkan bahwa fasilitas belajar adalah sarana dan prasarana yang diperlukan dalam kegiatan belajar disekolah. Komponen yang berasal dari alat produksi berupa Pendidikan sebagai sarana dan prasaran sebagai tempat dan proses Pendidikan.

Menurut Barnawi dan Arifin dalam Faizal Fathurrokhman (2020, hlmn 3334) menjelaskan bahwa sarana dan prasana dapat diklasifikasikan menjadi 3 macam, diantaranya sebagai berikut:

1) Berdasarkan habis tidaknya dibagi menjadi dua yaitu:

a) Sarana pendidikan yang habis dipakai

Bahan atau alat yang digunakan dapat habis dalam waktu relatif singkat disebut juga dengan sarana pendidikan yang habis pakai. Contohnya: tinta, kapur, kertas tulis, dan bahan kimia praktikum.

b) Sarana pendidikan yang tahan lama

Sarana pendidikan yang bertahan lama merupakan bahan atau alat yang digunakan secara berkelanjutan dalam waktu relatif lama. Contohnya: meja, kursi, atlas, globe, dan alat olahraga.

2) Berdasarkan bergerak tidaknya saat pembelajaran dibagi menjadi dua yaitu:

a) Sarana pendidikan yang bergerak

Sarana pendidikan yang bergerak adalah sarana pendidikan yang dapat digerakkan sesuai kebutuhan dari pemakainya. Contohnya: meja, kursi, lemari, dan peralatan praktik.

b) Sarana pendidikan yang tidak bergerak

Sarana pendidikan yang tidak bergerak adalah sarana pendidikan yang tidak dapat dipindahkan. Contohnya: LCD yang dipasang permanen, kabel listrik yang dipasang permanen.

3) Berdasarkan hubungan dengan proses pembelajaran yaitu:

a) Alat pelajaran

Alat pelajaran berkaitan dengan alat yang secara langsung digunakan dalam proses pembelajaran. Contohnya: buku pelajaran, alat peraga, dan alat tulis.

b) Alat peraga

Alat peraga berkaitan dengan alat bantu untuk memudahkan proses pembelajaran seperti halnya benda atau peragaan yang dilakukan guru untuk mengkonkretkan suatu materi pelajaran.

c) Media pengajaran 
Media pengajaran berkaitan dengan sarana pendidikan yang memiliki fungsi sebagai perantara dalam proses pembelajaran, sehingga efektivitas untuk mencapai tujuan pembelajaran dapat meningkat. Contohnya: media pengajaran audio, visual, dan audiovisual.

\section{Peran Guru}

Guru adalah seseorang yang berjasa dalam dunia pendidikan, karena guru adalah orang yang memberikan ilmu pengetahuan. Menurut Nawawi (2015: hlmn 280) Guru adalah orang dewasa yang karena peranannya berkewajiban memberikan pendidikan kepada anak didik. Orang tersebut mungkin berpredikat sebagai ayah atau ibu, guru, ustad, dosen ulama dan sebagainya.

Guru adalah seorang pendidik yang profesional, guru merupakan salah satu faktor utama bagi terciptanya generasi penerus bangsa. Dengan keilmuan yang dimilikinya, dia dapat menjadikan anak didik menjadi orang yang cerdas. UndangUndang Nomor 20 Tahun 2003 Pasal 39 Tentang Sistem Pendidikan Nasional, Menyatakan bahwa pendidik merupakan tenaga profesional yang bertugas merencanakan dan melaksanakan proses pembelajaran, menilai hasil pembelajaran, melakukan pembimbingan dan pelatihan, serta melakukan penelitian dan pengabdian kepada masyarakat, terutama bagi pendidik pada perguruan tinggi.

Seorang guru memegang peranan yang sangat penting dalam dunia pendidikan. Seperti halnya peserta didik, guru memiliki peranan penting dalam dunia pendidikan khususnya pada saat kegiatan belajar mengajar, karena pada dasarnya peserta didik memerlukan peran seorang guru dalam proses perkembangan diri dan pengoptimalan bakat dan kemampuan yang dimiliki.

Penyampaian materi pelajaran hanyalah merupakan salah satu dariberbagai kegiatan dalam belajar sebagai suatu proses yang dinamis dalam segala fase dan proses perkembangan siswa. Guru memiliki beberapa peran yang harus di munculkan pada saat kegiatan belajar mengajar. Menurut Sofan Amri, (2013, hlmn 30) Guru memiliki peran dalam aktivitas pembelajaran, yaitu sebagai:

a) Korektor, Guru menilai dan mengoreksi semua hasil belajar, sikap, tingkah, dan perbuatan siswa baik di sekolah maupun di luar sekolah evaluator.

b) Inspirator, Guru memberikan inspirasi kepada siswa mengenai cara belajar yang baik.

c) Informator, Guru memberikan informasi yang baik dan efektif mengenai materi yang telah di programkan serta informasi perkembangan ilmu pengetahuan dan teknologi.

d) Organisator, Guru berperan mengelola berbagai kegiatan akademik baik intrakurikuler maupun ekstrakurikuler sehingga tercapai efektivitas dan efisiensi anak didik.

e) Motivator, Guru dituntut untuk dapat mendorong anak didiknya agar senantiasa memiliki motivasi tinggi dan aktif belajar.

f) Inisiator, Guru menjadi pencetus ide-ide kemajuan dalam pendidikan dan Pengajaran.

g) Fasilitator, Guru hendaknya dapat menyediakan fasilitas yang memungkinkan anak didik dapat belajar secara optimal.

h) Pembimbing, Guru memberikan bimbingan kepada anak didiknya dalam 
menghadapi tantangan maupun kesulitan belajar.

i) Demonstrator, Guru dituntut untuk dapat memperagakan apa yang diajarkan secara didaktis, sehingga anak didik dapat memahami pelajaran secara optimal.

j) Pengelola kelas, Guru hendaknya dapat mengelola kelas dengan baik, karena kelas adalah tempat berhimpun guru dan siswa

k) Mediator, Guru dapat berperan sebagai penyedia media dan penengah dalam proses pembelajaran peserta didik.

I) Supervisor, Guru hendaknya dapat membantu, memperbaiki dan menilai secara kritis proses pembelajaran yang dilakukan sehingga dapat optimal

m) Evaluator, Guru dituntut untuk mampu menilai produk pembelajaran serta proses pembelajaran.

3. Hasil Belajar Online

Menurut Kunandar (2013, hlmn 62) mengatakan bahwa "hasil belajar adalah kompetensi atau kemampuan tertentu baik kognitif, afektif maupun psikomotorik yang dicapai atau dikuasai peserta didik setelah mengikuti proses b elajar mengajar". Sementara Menurut Sudijono (2012:32) menyatakan bahwa "hasil belajar adalah sebuah tindakan evaluasi yang dapat mengungkapkan aspek proses berpikir, juga dapat mengungkapkan aspek kejiwaan lainnya seperti aspek nilai atau sikap dan aspek keterampilan yang melekat pada diri siswa itu sendiri". Hal ini yang dapat menggabarkan hasil belajar siswa atau pencapaian siswa melalui kegiatan belajar.

Penilaian hasil belajar berbasis daring merupakan penilaian yang dilakukan berdasarkan apa yang tampak dan secara menyeluruh selama satu tema. Pada umumnya penilaian hasil belajar yang dilakukan secara daring dengan menugasakan siswa untuk mengerjakan sebuah soal yang ada dalam LKPD. Penilaian hasil belajar daring merupakan proses pengumpulan informasi tentang perkembangan peserta didik serta pencapaian pembelajaran yang dilakukan oleh peserta didik secara daring melalui media - meida pembelajaran yakni grup whatsAap, zoom, atau google classroom. Tujuan suatu pembelajaran telah benarbenar dicapai oleh peserta didik dapat dibuktikan memalui berbagai teknik. faktor-faktor yang mempengaruhi belajar banyak jenisnya, tetapi dapat digolongkan menjadi dua golongan yaitu saja, yaitu faktor intern dan faktor ekstern. Faktor intern adalah faktor yang ada dalam diri individu yang sedang belajar, sedangkan faktor ekstern adalah faktor yang ada di luar individu. Setiap kegiatan belajar menghasilkan suatu perubahan yang khas sebagai hasil belajar. Hasil belajar dapat dicapai peserta didik melalui usaha-usaha sebagai perubahan tingkah laku yang meliputi ranah kognitif, afektif dan psikomotorik, sehingga tujuan yang telah ditetapkan tercapai secara optimal. Hasil belajar yang diperoleh peserta didik tidak sama karena ada beberapa faktor yang mempengaruhi keberhasilannya dalam proses belajar.

Pengertian hipotesis menurut sugiyono (2010, hlmn 96), "hipotesis merupakan jawaban sementara terhadap permasalahan penelitian, di mana rumusan masalah penelitian telah dinyatakan dalam bentuk kalimat pernyataan".

H1: Terdapat pengaruh fasilitas belajar terhadap hasil belajar onlinesiswa di SMK Pasundan 4 Bandung 
H2: Terdapat pengaruh peran guru terhadap hasil belajar online siswa di SMK Pasundan 4 Bandung.

H3: Terdapat pengaruh fasilitas belajar dan peran guru terhadap hasil belajar online siswa di SMK Pasundan 4 Bandung.

\section{METODOLOGI PENELITIAN}

Menurut Suharsimi Arikunto (2010:203), menyebutkan bahwa "metode penelitian adalah cara yang digunaka oleh peneliti dalam mengumpulkan data penelitian. Dalam penelitian ini metode penelitian yang digunakan adalah metode penelitian kuantitatif. Adapun metode kuantitatif menurut Sugiyono (2018, hlm. 8) mengatakan "Metode penelitian kuantitatif dapat diartikan sebagai metode penelitian yang berlandaskan pada filsafat positivisme, digunakan untuk meneliti populasi atau sampel tertentu, pengumpulan data menggunakan instrument penelitian, analisis data bersifat kuantitatif/statistik, dengan tujuan untuk menguji hipotesis yang telah ditetapkan."

Berdasarkan penjelasan diatas penelitian ini menggunakan penelitian noneksperimen dengan metode penelitian kuantitatif yang bertujuan untuk menentukan populasi yang akan diteliti dengan Teknik pemngambilan data secara random.

\section{SUBJEK DAN OBJEK PENELITIAN}

Subjek penelitian adalah seluruh siswa kelas X BDP 1 SMK Pasundan 4 Bandung . Adapun dalam penelitian ini yang menjadi objek penelitian adalah hasil belajar online (Y) peserta didik X BDP 1 SMK Pasundan 4 Bandung. Adapun variabel yang mempengaruhi dalam penelitian ini adalah fasilitas belajar (X1) dan peran guru (X2).

\section{TEKNIK PENGUMPULAN DATA}

Adapun teknik pengumpulan data pada penelitian ini yaitu menggunakan angket dan soal tes yang akan disebarkan kepada siswa kelas X BDP 1 SMK Pasundan 4 Bandung.

\section{ANALISIS DATA}

Setelah data terkumpul, selanjutnya dilakukan analisis terhadap data penelitian. Adapun langkah analisis tersebut adalah sebagai berikut:

1. Uji Normalitas

2. Uji Multikolinearitas

3. Uji Heteroskedastisitas

4. Uji Regresi Linier Berganda

5. Uji Koefisien Determinasi

6. Pengujian Hipotesis Secara Simultan (Uji F)

7. Pengujian Hipotesis Secara Parsial (Uji t)

\section{HASIL PENELITIAN}

1. Uji normalitas

Uji normalitas digunakan untuk apakah data terdistribusi normal atau tidak, dengan menggunakan grafik. Normal tidaknya data dapat dideteksi juga level plot grafik histogram. Uji normalitas dengan menggunakan alat uji analisis metode Kolmogorov Smirnov. Berikut tabel hasil uji metode Kolmogorov Smirnov. 
Tabel 2

Uji Normalitas

\begin{tabular}{|l|l|l|l|}
\hline $\begin{array}{l}\text { Nilai Kolmogorov- } \\
\text { Smirnov Z }\end{array}$ & Asymp. Sig & Kriteria & Keterangan \\
\hline 0,200 & 0,093 & $>0,05$ & Data Normal \\
\hline
\end{tabular}

Sumber: Hasil Pengolahan Data Pada IBM SPSS Statistic Version 25.0

Dari hasil Pengolahan Data Pada IBM SPSS Statistic Version 25.0 diperoleh nilai signifikan 0,200>0,05, maka dapat disimpulkan bahwa nilai residual berdistribusi normal.

2. Uji Multikolinearitas

Untuk mendeteksi ada tidaknya multikoliniearitas dalam model regresi diilakukan dengan melihat nilai tolerance dan nilai Variance Inflation Factor (VIF) yang dapat dilihat dari output SPSS.

Tabel 3

Uji Multikoloniretas

\begin{tabular}{|l|l|r|r|}
\hline \multirow{2}{*}{\multicolumn{2}{|c|}{}} & \multicolumn{2}{|c|}{$\begin{array}{c}\text { Collinearity } \\
\text { Statistics }\end{array}$} \\
\cline { 2 - 4 } \multicolumn{2}{|l|}{ Model } & Tolerance & \multicolumn{1}{c|}{ VIF } \\
\hline \multirow{2}{*}{1} & Fasilitas Belajar & 0.837 & 1.195 \\
\cline { 2 - 4 } & Peran Guru & 0.837 & 1.195 \\
\hline
\end{tabular}

Sumber: Hasil Pengolahan Data Pada IBM SPSS Statistic Version 25.0

Berdasarkan tabel diatas multikolinearitas diatas dapat diketahui bahwa antar variabel bebas tidak terjadi multikolinearitas, sebab hasil perhitungan nilai tolerance dari tiap variabel independen tidak ada yang meunjukkan hasil kurang dari 0,10 dan hasil perhitungan nilai variance inflation factor (VIF) juga menunjukkan hasil tiap variabel independen tidak ada yang lebih dari 10. Dapat disimpulkan bahwa tidak terdapat multikolinearitas antar variabel independen dalam model regresi ini.

3. Uji Heteroskedastisitas

Untuk mendeteksi adanya heteroskedastisitas dilakukan dengan melihat grafik plot antara nilai prediksi variabel terikat (ZPRED) dengan residualnya (ZRESID), jika tidak ada pola tertentu serta titik - titik menyebar di atas dan di bawah angka nol pada sumbu Y, maka tidak terjadi heteroskedastisitas.

Berdasarkan hasil uji heterokedastisitas diatas menunjukkan bahwa model regresi tidak mengandung adanya gejala heterokedastisitas. Dapat dilihat dari titik-titik yang menyebar secara acak diatas dan di bawah angka 0 pada sumbu $Y$ dan tidak membentuk pola terstentu, sehingga dapat disimpulkan bahwa model regresi ini tidak terdapat gejala heterokedastisitas.

4. Uji Regresi Linier Berganda

Uji ini diperlukan dalam mengetahui koefisien-koefisien regresi serta signifikansi sehingga dapat digunakan dalam menjawab hipotesis yang ada. Hasil analisis regresi linier berganda dapat dilihat pada tabel dibawah ini: 
Tabel 4

Uji Lienar Berganda

\begin{tabular}{|l|l|r|r|r|r|c|}
\hline \multirow{2}{*}{ Model } & \multicolumn{2}{|c|}{$\begin{array}{l}\text { Unstandardize } \\
\text { dCoefficients }\end{array}$} & \multicolumn{2}{l|}{$\begin{array}{l}\text { Standardize } \\
\text { d } \\
\text { Coefficients }\end{array}$} & & \\
\cline { 2 - 7 } & \multicolumn{1}{|c|}{ B } & Std. Error & \multicolumn{1}{c|}{ Beta } & & \multirow{2}{*}{ Sig. } \\
\hline \multirow{2}{*}{1} & (Constant) & 1.638 & 0.347 & & 4.422 & 0.000 \\
\cline { 2 - 7 } & Fasilitas Belajar & 0.513 & 0.109 & 0.557 & 3.116 & 0.001 \\
\cline { 2 - 5 } & Peran Guru & 0.577 & 0.095 & 0.562 & 3.870 & 0.000 \\
\hline
\end{tabular}

Sumber: Hasil Pengolahan Data Pada IBM SPSS Statistic Version 25.0

Berdasarkan tabel hasil analisis regresi linier berganda di atas diperoleh persamaan sebagai berikut:

$\mathrm{Y}=1.638-0.513 \mathrm{X} 1+0,577 \mathrm{X} 2+0,347$

Dilihat dari persamaan diatas maka dapat dijelaskan sebagi berikut:

1) Berdasarkan persamaan regresi linier berganda diatas diketahui bahwa nilai konstanta sebesar 1.638, artinya bila variabel bebas fasilitas belajar dan peran guru dianggap konstan maka dapat diprediksi fasilitas belajar serta peran guru sebesar 1.638 satuan.

2) Variabel fasilitas belajar (X1) pada model regres linier berganda diatas nilai koefisien sebesar 0,513 , artinya apabila nilai variabel fasilitas belajar meningkat dan yang lain konstan, maka dapat diprediksi nilai variabel turun sebesar 0.513 .

3) Variabel peran guru (X2) pada model regres linier berganda diatas nilai koefisien sebesar 0,577 , artinya apabila nilai variabel peran guru meningkat dan yang lain konstan, maka dapat diprediksi nilai variabel naik sebesar 0,577 .

5. Uji Koefisien Determinasi

Koefisien determinasi (R2) digunakan dalam mengukur seberapa jauh kemampuan model dalam menggambarkan variasi variabel independen. Nilai R2 yang kecil maka kemampuan variablel - variabel independen dalam menjelaskan variasi variabel independen sangat terbatas. Nilai koefisien determinasi (R2) dapat dilihat pada tabel dibawah ini:

Tabel 5

Uji Koefisien Determinasi

\begin{tabular}{|l|rr|r|r|r|}
\hline \multicolumn{5}{|c|}{ Model Summary $^{\mathbf{b}}$} \\
\hline Model & $\mathrm{R}$ & & R Square & $\begin{array}{c}\text { Adjusted R } \\
\text { Square }\end{array}$ & $\begin{array}{c}\text { Std. Error of } \\
\text { the Estimate }\end{array}$ \\
\hline 1 & & $.838^{\mathrm{a}}$ & 0.702 & 0.669 & 4.9462 \\
\hline
\end{tabular}

Sumber: Hasil Pengolahan Data Pada IBM SPSS Statistic Version 25.0

Berdasarkan pada tabel diatas, hasil uji koefisien determinasi (R2) diatas menunjukkan nilai Adjusted R Square (R2) sebesar 0.838. Hal ini menunjukkan bahwa variabel independen hasil belajar online dapat dijelaskan oleh variabel dependen fasilitas belajar dan peran guru sebesar $83,8 \%$, sedangkan sebesar $16,2 \%$ dipengaruhi sumbangan efektif: 
Tabel 6

Sumbangan Efektif

\begin{tabular}{|c|c|c|c|}
\hline \multicolumn{4}{|c|}{ Coefficients } \\
\hline \multirow{2}{*}{\multicolumn{2}{|c|}{ Model }} & $\begin{array}{l}\text { Standardized } \\
\text { Coefficients }\end{array}$ & Correlations \\
\hline & & Beta & Zero-order \\
\hline \multirow[t]{2}{*}{1} & Fasilitas Belajar & & $.620^{*}$ \\
\hline & Peran Guru & & $.636^{*}$ \\
\hline
\end{tabular}

a. Dependent Variable: Hasil Belajar Online

Sumber: Hasil Pengolahan Data Pada IBM SPSS Statistic Version 25.0

Variabe $X 1$ ke $Y: 0,557 \times 0.620=$

$34,5 \%$ Variabel $X 2$ ke $Y: 0.582 \times$

$0.636=35,8 \%$

6. Pengujian Hipotesis Secara Simultan (Uji F)

Uji simultan (Uji F) dalam penelitian ini digunakan untuk mengetahui pengaruh fasilitas belajar (X1) dan peran guru $(\mathrm{X} 2)$ terhadap hasil belajar online $(\mathrm{Y})$ secara bersama-sama (simultan).

Tabel 7

Hasil Uji F

\begin{tabular}{|c|c|c|c|c|c|c|}
\hline \multicolumn{2}{|c|}{ Model } & $\begin{array}{l}\text { Sum of } \\
\text { Squares }\end{array}$ & Df & $\begin{array}{l}\text { Mean } \\
\text { Square }\end{array}$ & $\mathrm{F}$ & Sig. \\
\hline \multirow[t]{3}{*}{1} & Regression & 123.212 & 2 & 103.252 & 6.408 & \multirow[t]{3}{*}{$.000^{\mathrm{b}}$} \\
\hline & Residual & 850.145 & 53 & 16.113 & & \\
\hline & Total & 973.357 & 55 & & & \\
\hline
\end{tabular}

Sumber: Hasil Pengolahan Data Pada IBM SPSS Statistic Version 25.0

Dari tabel diatas menunjukkan bahwa nilai signifikansi lebih kecil dari 0.05 $(0.000<0.05)$, sehingga dapat disimpulkan bahwa masing- masing variabel independen Fasilitas Belajar dengan signifikansi $(0,000)$ dan Peran Guru $(0,000)$, secara bersama - sama berpengaruh terhadap variabel dependen (Hasil Belajar Online Siswa).

7. Pengujian Hipotesis Secara Parsial (Uji t)

Dalam penelitian ini uji statistik t digunakan dalam mengetahui secara parsial pengaruh variabel kinerja perusahaan yang diproksikan dalam dewan direksi, ukuran perusahaan kriteria yang digunakan dalam menguji statistik. Hasil uji statistik dapat dilihat pada tabel dibawah ini: 
Tabel 8

Hasil Uji Hipotesis secara Parsial (Uji t)

\begin{tabular}{llcc}
\hline \multicolumn{2}{c}{ Model } & T & Sig. \\
\hline 1 (Constant) & 4.219 & 0,000 \\
Fasilitas Belajar & 3.116 & 0.001 \\
Peran guru & 3.870 & 0.000 \\
\hline \multicolumn{2}{l}{ a. Dependent Variable: Hasil belajar online } \\
\hline \multicolumn{2}{c}{ Sumber: Hasil Pengolahan Data Pada IBM SPSS Statistic Version 25.0 }
\end{tabular}

Dari tabel diatas bahwa fasilitas belajar mempunyai nilai signifikansi sebesar $0.001<0.05$ dan untuk peran guru mempunyai nilai signifikansi sebesar $0.000<0.05$, sehingga dapat disimpulkan bahwa fasilitas belajar dan peran guru berpengaruh terhadap hasil belajar online siswa. Dari data diatas, dapat disimpulkan bahwa fasilitas belajar dan peran guru bersama - sama berpengaruh terhadap hasil belajar online siswa, dilihat dari uji yang sudah dilakukan diatas.

\section{PEMBAHASAN}

1) Pengaruh fasilitas belajar terhadap hasil belajar online siswa di SMK Pasundan 4 Bandung

Fasilitas belajar adalah sarana dan prasarana yang diperlukan dalam kegiatan belajar disekolah. Komponen yang berasal dari alat produksi berupa pendidikan sebagai sarana dan prasaran sebagai tempat dan proses Pendidikan. Sarana dan prasarana disini yang menunjang dan mempermudah peserta didik dalam melaksanakan pembelajaran, dimana pada saat ini pembelajaran harus dilakukan secara online dan mendapatkan hasil belajar online yang sesuai dengan afektif, kognitif, dan psikomotor atau harus sesuai dengan ketentuan yang ada. Pengaruh fasilitas belajar terhadap hasil belajar online siswa diukur menggunakan Instrumen angket atau kuesioner. Angket atau kuesioner digunakan untuk mengukur sbserapa besar pengaruh fasilitas belajar terhadap hasil belajar online siswa.

Untuk mengumpulkan data - data pada penelitiaan ini dilakukan dengan menyebar angket melalui google form untuk di isi oleh perserta didik kelas X BDP semester ganjil di SMK Pasundan 4 Bandung. Kuesioner/angket pada variabel X1 yaitu fasilitas belajar diukur menggunakan 8 item pernyataan dalam kuesioner/angket. Kemudian data tersebut diolah dan dianalisi dengan menggunakan aplikasi IBM SPSS Statistics Version 25.0.

Dapat dilihat dari rata-rata tanggapan peserta didik pada kuesioner diperoleh hasil baik yang mempengaruhi pada rata-rata hasil tes pengaruh fasilitas belajar terhadap hasil belajar online menjadi sedang atau cukup baik yang dibuktikan dengan hasil persentase rata-rata tes hasil belajar online siswa pada mata pelajaran ekonomi sebesar $89,20 \%$. Variabel $X 1$ terhadap $Y$ menyumbang pengaruh sebesar 0,322 atau 34,5\%. Dari data - data tersebut dapat disimpulkan bahwa fasilitas belajar cukup berpengaruh terhadap hasil belajar online siswa di kelas X BDP SMK Pasundan 4 Bandung, survey pada mata pelajaran ekonomi semester ganjil dinyatakan sudah baik. 
2) Pengaruh peran guru dalam kegiatan pembelajaran terhadap hasil belajar online siswa di SMK Pasundan 4 Bandung

Seorang guru memegang peranan yang sangat penting dalam dunia pendidikan. Pada dasarnya peserta didik memerlukan peran seorang guru dalam proses perkembangan diri dan pengoptimalan bakat dan kemampuan yang dimiliki. Pengumpulan data pada penelitiaan ini dilakukan dengan menyebar angket melalui google form untuk di isi oleh perserta didik kelas X BDP semester ganjil di SMK Pasundan 4 Bandung. Kuesioner/angket pada variabel X2 yaitu peran guru diukur menggunakan 12 item pernyataan dalam kuesioner/angket. Selanjutnya data tersebut diolah dan dianalisi dengan menggunakan aplikasi IBM SPSS Statistics Version 25.0.

Uraian hasil penelitian yang telah dilakukan keseluruhan diperoleh data hasil ratarata tiap butir pernyataan kuesioner peran guru adalah 4,11 dengan persentase sebesar $82,86 \%$. Hal ini menunjukan bahwa peran guru pada kelas X BDP semester ganjil di SMK Pasundan 4 Bandung memiliki nilai baik, dilihat dari rata rata jawaban reponden dengan kriteria setuju.

Dilihat dari rata-rata tanggapan peserta didik pada kuesioner diperoleh hasil baik yang mempengaruhi pada rata-rata hasil tes hasil belajar online siswa pada mata pelajaran ekonomi dengan nilai rata - rata 4,50 presentase sebesar $89,20 \%$. Variabel $\mathrm{X} 2$ terhadap $\mathrm{Y}$ menyumbang pengaruh sebesar 0,322 atau 35,8\%. Dari data - data tersebut dapat disimpulkan bahwa peran guru cukup berpengaruh terhadap hasil belajar online siswa di kelas X BDP SMK Pasundan 4 Bandung, survey pada mata pelajaran ekonomi semester ganjil.

3) Pengaruh fasilitas belajar online dan peran guru terhadap hasil belajar online siswa di SMK Pasundan 4 Bandung

Fasilitas Belajar dan Peran guru merupakan aspek yang sangat penting dalam mendukung hasil belajar online siswa. Dengan fasilitas belajar dan peran guru yang memadai diharapkan akan mendorong hasil belajar online siswa. Penelitian ini bertujuan untuk mengetahui seberapa besar pengaruh fasilitas belajar dan peran guru terhadap hasil belajar online siswa di kelas X BDP SMK Pasundaan 4 Bandung.

Berdasarkan hasil analisis regresi linier berganda di atas diperoleh persamaan sebagai berikut: $Y=1.638-0.513 X 1+0,577 X 2+0,347$

Dimana:

$Y=$ Hasil Belajar Online

X1 = Fasilitas Belajar X2 = Peran Guru

Berdasarkan persamaan regresi linier berganda diatas diketahui bahwa nilai konstanta sebesar 1.638, artinya bila variabel bebas fasilitas belajar dan peran guru dianggap konstan maka dapat diprediksi fasilitas belajar serta peran guru sebesar 1.638 satuan. Variabel fasilitas belajar (X1) pada model regres linier berganda diatas nilai koefisien sebesar 0,513 , artinya apabila nilai variabel fasilitas belajar meningkat dan yang lain konstan, maka dapat diprediksi nilai variabel turun sebesar 0.513. Variabel peran guru (X2) pada model regres linier berganda diatas nilai koefisien sebesar 0,577 , artinya apabila nilai variabel peran guru meningkat dan yang lain konstan, maka dapat diprediksi nilai variabel naik sebesar 0,577. Terdapat nilai koefisien sebesar 0,347 pada model regres linier berganda, artinya 
bahwa banyak sekali variabel - variabel bebas yang mempengaruhi variabel terikat $(\mathrm{Y})$.

Dalam uji $F$ atau simultan penelitian ini variabel fasilitas belajar (X1) fsm peran guru (X2) memiliki taraf signifikansi 0,000 dimana nilainya lebih kecil dari 0,050 atau $5 \%$, sehingga dapat dinyatakan bahwa variabel fasilitas belajar (X1) dab peran guru (X2) berpengaruh secara simultan (Uji F) terhadap hasil belajar online siswa. Hasil diatas menunjukan bahwa fasilitas belajar dan peran guru menjadi faktor penting yang dapat mendorong hasil belajar online siswa. Siswa yang didukung oleh fasilitas belajar yang memadai dan peran guru yang berkompeten akan belajar secara efektif dan efisien.

\section{PENUTUP}

\section{Kesimpulan}

Berdasarkan hasil analisis data dan pengujian hipotesis yang dilakukan peneliti pada peserta didik kelas X BDP SMK Pasundan 4 Bandung di semester ganjil mengenai pengaruh fasilitas belajar dan peran guru terhadap hasil belajar online siswa, maka ditarik kesimpulan sebagai berikut:

1. Berdasarkan hasil peneliti dan pembahasan yang telah dilaksanakan dapat disimpulkan bahwa secara keseluruhan peserta didik mengenai fasilitas belajar menunjukan kualifikasi "ragu - ragu" ditunjukan dengan rata - rata skor sebesar 3,11 dengan persentase sebesar 62,40\%. Dapat ditafsirkan bahwa fasilitas belajar dinyatakan ragu - ragu atau netral. Variabel X1 terhadap $\mathrm{Y}$ menyumbang pengaruh sebesar 0,322 atau $34,5 \%$. Hal tersebut berdasarkan pada jawban responden yang dilihat dari fasilitas belajar belum memadai, dengan adanya penelitian ini, fasilitas belajar yang memadai diharapkan dapat membantu proses belajar mengajar.

2. Berdasarkan hasil peneliti dan pembahasan yang telah dilaksanakan dapat disimpulkan bahwa secara keseluruhan peserta didik kelas X BDP SMK Pasundan 4 Bandung menyatakan bahwa peran guru memiliki nilai baik, dari data hasil rata - rata yang diperoleh tiap butir pernyataan kuesioner peran guru adalah 4,11 dengan persentase sebesar $82,86 \%$. Variabel X2 terhadap $Y$ menyumbang pengaruh sebesar 0,322 atau $35,8 \%$. Hal ini menunjukan bahwa peran guru pada kelas X BDP semester ganjil di SMK Pasundan 4 Bandung memiliki nilai baik, dilihat dari rata - rata jawaban reponden dengan kriteria setuju.

3. Pengaruh fasilitas belajar dan peran guru memberikan pengaruh yang baik terhadap hasil belajar online siswa kelas X BDP SMK Pasundan 4 Bandung. Hal ini dapat ditunjukan dengan hasil perhitungan analisis regresi linear berganda yaitu $Y=1.638-0.513 \times 1+0,577 \times 2+0,347$ yang artinya, bila variabel bebas fasilitas belajar dan peran guru dianggap konstan maka dapat diprediksi fasilitas belajar serta peran guru sebesar 1.638 satuan. Koefisien regresi $\mathrm{X} 1$ sebesar 0,513 , artinya apabila nilai variabel fasilitas belajar meningkat dan yang lain konstan, maka dapat diprediksi nilai variabel turun sebesar 0.513 . dan koefisien regresi X2 sebesar 0,577 , artinya apabila nilai variabel peran guru meningkat dan yang lain konstan, maka dapat diprediksi nilai variabel naik sebesar 0,577 . 


\section{DAFTAR PUSTAKA}

\section{Sumber Buku :}

Ahmad Hadiri, Nawawi., (2014) Menjadi guru unggul, Yogyakarta: Ar-Ruzz Media. Amri, Sofan. 2013. Pengembangan \& Model Pembelajaran Dalam Kurikulum 2013. Jakarta: PT. Prestasi Pustakarya.

Arikunto, Suharsimi, (2010), Prosedur Penelitian; Suatu Pendekatan Praktik, Jakarta: Rineka Cipta

Bafadal, I. (2004), Manajemen Perlengkapan sekolah, teori dan aplikasinya. Jakarta: Bumi Aksara

Kunandar (2013), Penilaian Hasil Belajar Peserta Didik Berdasarkan Kurikulum 2013, Jakarta: Raja Grafindo Persada

Moch, U. U. (2008). Strategi Pembelajaran. Jakarta: Earlangga.

Sudijono, A. (2012). Pengantar Evaluasi Pendidikan. Jakarta: PT. RajaGrafindo Persada.

Sugiyono, (2012), Metode Penelitian Kombinasi, Bandung: Alfabeta.

Sugiyono, (2015), Metode Penelitian Kuantitatif dan Kualitatif dan R\&D Cetakan ke-11, Bandung: Alfabeta

\section{Sumber Jurnal :}

Novita Arseni dan Abdul Hamid. (2015). Penggunaan Media Pembelajaran Online - Offline dan Komunikasi Interpersional Terhadap Hasil Belajar Bahasa Inggris. Jurnal Teknologi Informasi dan Komunikasi dalam Pendidikan, Volume 2, Nomor 1

\section{Sumber Skripsi :}

Wicaksono, Pekik (2012) Pengaruh Fasilitas Belajar, Motivasi Belajar dan Minat Belajar terhadap Prestasi Belajar siswa Kelas X SMK Muhamadiyah Prambanan Tahun Ajaran 2011/2012, Skripsi. Yogyakarta: Universitas Negeri Yogyakarta

Fathurrakhman, Faizal., (2020), Hubungan Fasilitas Belajar dan Minat Belajar dengan Hasil Belajar IPS Siswa Kelas V SDN Kecamatan Batang Kabupaten Batang. Skripsi. Semarang: Universitas Negeri Semarang. 